IZA DP No. 9584

Do They Find You on Facebook?

Facebook Profile Picture and Hiring Chances

Stijn Baert

December 2015 


\title{
Do They Find You on Facebook? Facebook Profile Picture and Hiring Chances
}

\author{
Stijn Baert \\ Ghent University, University of Antwerp, \\ Université catholique de Louvain and IZA
}

\section{Discussion Paper No. 9584 December 2015}

\author{
IZA \\ P.O. Box 7240 \\ 53072 Bonn \\ Germany \\ Phone: +49-228-3894-0 \\ Fax: +49-228-3894-180 \\ E-mail: iza@iza.org
}

\begin{abstract}
Any opinions expressed here are those of the author(s) and not those of IZA. Research published in this series may include views on policy, but the institute itself takes no institutional policy positions. The IZA research network is committed to the IZA Guiding Principles of Research Integrity.

The Institute for the Study of Labor (IZA) in Bonn is a local and virtual international research center and a place of communication between science, politics and business. IZA is an independent nonprofit organization supported by Deutsche Post Foundation. The center is associated with the University of Bonn and offers a stimulating research environment through its international network, workshops and conferences, data service, project support, research visits and doctoral program. IZA engages in (i) original and internationally competitive research in all fields of labor economics, (ii) development of policy concepts, and (iii) dissemination of research results and concepts to the interested public.
\end{abstract}

IZA Discussion Papers often represent preliminary work and are circulated to encourage discussion. Citation of such a paper should account for its provisional character. A revised version may be available directly from the author. 
IZA Discussion Paper No. 9584

December 2015

\section{ABSTRACT \\ Do They Find You on Facebook? Facebook Profile Picture and Hiring Chances*}

We investigate whether the publicly available information on Facebook about job applicants affects employers' hiring decisions. To this end, we conduct a field experiment in which fictitious job applications are sent to real job openings in Belgium. The only characteristic in which these candidates differ is the unique Facebook profile that can be found online with their name. Candidates with the most beneficial Facebook picture obtain approximately 39\% more job interview invitations compared to candidates with the least beneficial picture. In addition, we find suggestive evidence for a higher effect of Facebook profile picture appearance on hiring chances when candidates are highly educated and when recruiters are female.

JEL Classification: $\quad$ C93, D83, J24, J79, L86

Keywords: $\quad$ hiring, screening, Facebook, Internet, personality, attractiveness

Corresponding author:

Stijn Baert

Ghent University

Sint-Pietersplein 6

9000 Gent

Belgium

E-mail: Stijn.Baert@UGent.be

\footnotetext{
${ }^{*}$ We are grateful to Bart Cockx for his comments that helped us to improve this study substantially; to Lynn Decuypere, Lisa Glorieux, Stefanie Notebaert, Anke Penninck and Willem Van Melkebeke for their research assistance; and to the participants of the annual conference of the European Society for Population Economics in 2013 and the World Conference of the Society of Labor Economists and the European Association of Labour Economists in 2015 for their constructive suggestions. The present research was approved by the Ethical Committee of the Faculty of Economics and Business Administration of Ghent University.
} 


\section{Introduction}

A recent theme in the popular media has been that employers increasingly employ personal information available on social networking websites (SNWs) such as Facebook, Linkedln and Twitter to make hiring decisions. ${ }^{1}$ Furthermore, contributions to the academic psychological literature show that this supposed use of SNWs by employers is, to some extent, rational. First, Kluemper and Rosen (2009) find that recruiters can reliably and accurately determine productivityrelated traits solely on the basis of one's personal information available on SNWs. Moreover, this information can be gained with little time and effort. Second, Back et al. (2010), Gosling et al. (2008) and Kramer and Winter (2008) show that appearance on SNWs reflects individuals' actual personality traits and not their self-idealisation. Consistent with this empirical finding, Roulin and Bangerter (2013) describe the information on the SNWs profiles of job candidates as "honest signals" of their ability and commitment.

Given the popular belief that SNWs are consulted for hiring decisions and the academic finding that this consultation could be rational, it is surprising that within peer-reviewed literature, the question of to what extent the information publicly available on SNWs does affect hiring decisions has received only little attention. The only academic study works we are aware of are six studies on self-reported use of SNWs by recruiters. ${ }^{2}$ These six studies are summarised in Table 1. Depending on the moment when and the country and sector where the survey is conducted, between 8.1\% (use of Facebook in Greece in 2009-2010) and 50.0\% (use of any SNWs in the United States in 2010) of the examined recruiters indicate that they employ SNWs when screening job candidates. In addition, while Gibbs et al. (2015) find that employers perceive SNWs as more useful in recruiting lower-level

\footnotetext{
${ }^{1}$ See, e.g., Broughton et al. (2013), CareerBuilder (2012), Clark (2006), Du (2007), Kravets (2013), Levinson (2010), Preston (2011), Shea and Wesley (2006), Stone (2006), SHRM (2011) and Zeidner (2007).

${ }^{2}$ Besides this literature, the effect of social networking appearance on hiring chances has also been tested by means of laboratory experiments (Bohnert and Ross, 2010; Roulin and Bangerter, 2013). However, these experiments do not allow one to measure the extent to which SNWs are used in practice when evaluating job candidates. A broader study on using online information about individuals in personnel selection is Berkelaar et al. (2015).
} 
employees than for higher-level employees, Madera and Chang (2011) report the opposite.

\section{<Table 1 about here.>}

The aforementioned literature based on self-reported information from employers suffers, in our opinion, from three methodological problems. First, employers' reported attitudes might not represent their actual hiring behaviour (Pager and Quillian, 2005). They might adapt their answers to their perception of whether the use of SNWs in the recruitment process is socially desirable. Second, even if the measures of SNWs use by employers based on self-reported information square actual behaviour, these measures would still not reveal the extent to which the information on SNWs affects hiring decisions. On the one hand, the information found by recruiters on SNWs might in many cases not yield explicit job-related information beyond the information found in candidates' written applications (Brown and Vaughn, 2011). On the other hand, recruiters may just use SNWs to confirm the hiring decision that they in fact already made (Elzweig and Peeples, 2009). Third, the analysis of self-reported information on the use of SNWs in screening job candidates is hampered by the variability in available information on candidates' profile pages due to variation in the extent to which these candidates are active on SNWs and their (customisable) privacy settings (Brown and Vaughn, 2011). This variability, which cannot be controlled based on employer self-reports, might be correlated with other determinants of employment opportunities (e.g., the gender, education level, region, sector and personality of the candidate). Not taking into account this variability in available information might, therefore, bias measures of how appearance on SNWs does affect hiring chances for different subpopulations.

To the best of our knowledge, our study is the first to directly investigate whether the information publicly available on SNWs affects hiring decisions. More concretely, we measure the extent to which job candidates' Facebook profile picture appearance affects their hiring chances. ${ }^{3}$ To this end, we conduct a

\footnotetext{
${ }^{3}$ For a definition and description of Social Networking Sites in general and Facebook in particular, we refer to
} 
randomised experiment in Belgium. We construct two template resumes and cover letters, equal in all job-relevant characteristics, for school graduates holding either the same secondary or tertiary education degree. These pairs of applications are sent to 1,056 genuine job openings. To each of both applications, we randomly assign one out of four facial pictures with diverging scores on perceived attractiveness and the Big Five Personality Dimensions. In half of the applications we send out, these pictures are directly pasted into the resumes, while for the other half of the applications, they are used as Facebook profile pictures. By monitoring the subsequent reactions from the employer side, the (absolute and relative) unequal treatment based on the pictures revealed by the Facebook profile (and resume) pictures is identified directly and can be given a causal interpretation.

The remainder of this study is structured as follows. In the next section, we describe the conducted experiment. In Section 3, we answer our research question by means of a statistical examination of the experimentally gathered data. We present measures of the extent to which the hiring chances of our fictitious job candidates are affected by their Facebook profile pictures (as such and relative to the effect of these pictures when pasted directly to their written application). In addition, we investigate whether the effect of Facebook profile picture appearance is heterogeneous by (i) the education level of the candidate, (ii) the gender of the recruiter, (iii) the level of customer contact in the posted job and (iv) the labour market tightness at the level of the occupation. The last section concludes the article and provides the reader with directions for future research.

Boyd and Ellison (2007) and Brown and Vaughn (2011); for a literature review of the scientific literature on Facebook, we refer to Caers et al. (2013), Rains and Brunner (2015), Roth et al. (2013), Wilson et al. (2012) and Zhang and Leung (2015); for a discussion on the ethical and legal issues for employers using Facebook to screen applicants, we refer to Brandenburg (2008), Brown and Vaughn (2011), Chauhan et al. (2013), Davison et al. (2011), Slovensky and Ross (2012) and Smith and Kidder (2010). 


\section{The Experiment}

\subsection{An Alternative Application of the Correspondence Experimentation Framework}

Over the past few decades, social and behavioural scientists in general and labour economists in particular have conducted various correspondence experiments to measure unequal treatment in the labour market. Within this type of experiment, pairs of fictitious job applications are sent to real job openings. These applications differ only in the characteristic that is to be tested. This characteristic is randomly assigned within each pair of applicants. By monitoring the subsequent call-back, unequal treatment in first hiring decisions based on this characteristic can be identified. This measure of unequal treatment can be given a causal interpretation. Selection based on individual unobservable characteristics is eliminated as the researcher fully controls the information available to the employer. This allows her/him to disentangle discrimination from alternative explanations of heterogeneous hiring outcomes, such as differences in preferences and behaviour at the employee side or differences in human capital.

In the beginning, correspondence experiments were exclusively applied to investigate racial and sex discrimination (Bertrand and Mullainathan, 2004; Pager, 2007; Riach and Rich, 2002). More recently, correspondence tests have been employed to study discrimination based on other grounds, such as age, beauty and sexual orientation (Baert et al., 2015b; Drydakis, 2009; Drydakis, 2011; Rooth, 2009). In addition, scholars have started to employ correspondence experiments to study phenomena other than labour market discrimination in strict sense, such as unemployment duration dependence and the labour market penalty of motherhood (Baert, 2014; Eriksson and Rooth, 2014; Kroft et al., 2013).

In the present study, on the one hand, we join in with the more recent correspondence experiments studying the effect of facial attractiveness (Lopez Bóo et al., 2013; Mauzer-Fazio and Lei, 2015; Rooth, 2009; Ruffle and Shtudiner, 2015), 
as half of our pairs of fictitious applicants differ only in the picture added to their resume. On the other hand, we distinguish ourselves from the former applications of the correspondence experimentation literature by letting the other half of our pairs of fictitious applicants differ only by a characteristic that cannot be evaluated directly from the written application, i.e., the candidates' publicly available Facebook picture.

We conducted our field experiment between November 2013 and May 2014 in the labour market of Flanders, the northern part of Belgium. During this period, we tested 1,056 vacancies in the database of the Public Employment Agency of Flanders, i.e., the region's most important job search channel. More concretely, we randomly selected 528 vacancies for jobs targeting labour market entrants with a secondary education degree (i.e., ISCED level 3$)^{4}$ in commerce and 528 vacancies for jobs targeting labour market entrants with a Master's degree (i.e., ISCED level 5 - Master) in commercial sciences. Two job applications of graduates, identical in terms of productivity-relevant characteristics, were sent to the selected vacancies. To each candidate within our pairs of applicants, we randomly assigned one out of four facial pictures diverging in attractiveness and personality traits. For half of the pairs, these pictures were employed as the pair members' Facebook profile picture. By monitoring the subsequent call-back for these pairs by profile picture, unequal treatment based on the candidates' Facebook profile picture could be identified. For the other half of the pairs, the same pictures were used as the pair members' resume picture. As a result, we were able to compare the effect of revealing the pictures as a Facebook profile picture to their effect when revealed as a resume picture. ${ }^{5}$

Our choice for Facebook profile picture appearance as a social media item potentially screened by employers is motivated as follows. First, with more than

\footnotetext{
${ }^{4}$ ISCED stands for International Standard Classification of Education.

${ }^{5}$ By also sending out pairs disclosing their facial picture as a resume picture, we anticipated a zero effect of the Facebook profile pictures on hiring outcomes. This zero effect could have been explained by two important reasons: (i) recruiters did not screen job candidates' Facebook profile pictures and/or (ii) the pictures we used did not yield diverging hiring chances if they were screened. A non-zero effect of these pictures, when pasted directly to one's resume, could have ruled out explanation (ii), if we were willing to assume that Facebook profile pictures and resume pictures affect, if they are screened, employers' hiring decisions roughly to an equal extent.
} 
1.49 billion monthly active users as of 30 June 2015, Facebook is the world's most popular SNW (Facebook, 2015). Second, a substantial fraction of the Facebook users allow other users to whom they are not connected as friends to see only their name and Facebook profile picture. Therefore, being only able to judge job candidates' Facebook profile picture is a situation in which many employers find themselves in reality. Third, allowing only (randomised) variation in our fictitious candidates' facial pictures keeps the controlled experimental setting feasible. Fourth, facial pictures nevertheless allow employers to screen candidates' attractiveness and personality traits. This is relevant information as, following a survey of the popular job search website CareerBuilder (2012), the most important aspect that recruiters mention with respect to screening job candidates' Facebook profiles is making inferences about these candidates' personality that might not be as easily obtained through traditional screening. ${ }^{6}$ In addition, peer-reviewed research shows that resume pictures revealing beneficial characteristics with respect to attractiveness and personality traits increase job candidates' hiring chances (Baert and Decuypere, 2014; Lopez Bóo et al., 2013; Mauzer-Fazio and Lei, 2015; Rooth, 2009; Ruffle and Shtudiner, 2015).

\subsection{Construction of Job Application Template Pairs}

For each of the aforementioned two academic degrees held by our fictitious applicants, we created two template applications comprising a resume and a cover letter. We will refer to them as the Type A and Type B application types. These types were equal in all productivity-relevant characteristics but differed in lay-out and details such as the particular cultural activity mentioned. To ensure that our application templates were realistic and representative, example applications of the Public Employment Agency of Flanders were used and calibrated for our purposes.

\footnotetext{
${ }^{6}$ Another important self-reported reason appears to be verifying information presented in candidates' written applications (Brown and Vaughn, 2011; CareerBuilder, 2012).
} 
The Type A and Type B applicants were single male graduates born, studying and living in comparable suburbs of the cities of Antwerp and Leuven. We appended a fictitious postal address (a real street but a non-existing street number) and a date of birth to all application templates. The applicants shared the following characteristics: Belgian nationality, work experience from two student jobs, adequate (and comparable) ICT and language skills, a driver's license and sports and cultural activities.

Our candidates graduated in June 2013, from a school with a comparable reputation, without any grade retention experience. In line with the particular vacancy to which the pair of applicants was sent, a specialisation was chosen. For the secondary education degree in commerce, the specialisations used were (i) commerce (no specific specialisation), (ii) accountancy, (iii) ICT, (iv) secretariat and languages and $(\mathrm{v})$ tourism. For the Masters in commercial sciences, the specialisations used were (i) accountancy and tax, (ii) financial management, (iii) human resource management, (iv) international affairs and (v) marketing management. These different specialisations allowed us to apply for various occupations. Testing multiple occupations (rather than just one) is important because it enabled us to avoid the danger inherent in many former correspondence experiments in which researchers simply selected an occupation with, potentially, a high (or low) surplus of the tested characteristic. In addition, the variety in occupations enabled us to measure heterogeneous treatment effects by customer contact level at the posted job level and labour market tightness at the occupation level.

It is important to note that the minimal differences between the Type A and Type B application templates could not bias our results as the treatment of interest, i.e., the candidate's facial picture, was, for each vacancy, randomly assigned to these types. Moreover, the regression analysis presented in Section 3.2 shows that these differences did not yield different call-back outcomes for our two template types. 


\subsection{Randomised Assignment of Facebook Profile and Resume Pictures}

The pictures used for our experiment were selected from those employed in the laboratory experiment of Baert and Decuypere (2014). In their study, which was to some extent a preparatory study for the present one, 195 raters scored 22 pictures of young graduates, selected from picture databases, on the Big Five Personality Dimensions (agreeableness, conscientiousness, emotional stability, extraversion and openness) and on attractiveness. ${ }^{7}$ Personality traits were rated using the TenItem Personality Inventory (Gosling et al., 2003) for each photograph. This yielded a single index for each personality trait between 1 and 7, for each picture. Attractiveness was measured by the participants' assessment of the statement "I see this person as attractive" on a 7-point Likert Scale, yielding a last index between 1 and 7 .

Based on the testers' rating, we identified four facial pictures with diverging scores on attractiveness and personality. These pictures are included in Appendix A (Figures A.1, A.2, A.3 and A.4). Picture 1 and Picture 2 are facial pictures that got beneficial scores. Picture 1 was chosen for its high score on attractiveness, on the one hand, and extraversion, agreeableness, emotional stability and openness, on the other hand. This picture, however, had only a moderate score with respect to the personality trait that is generally found to drive productivity the most: conscientiousness (Barrick and Mount, 1991; Heineck and Anger, 2010; Mueller and Plug, 2006; Nyhus and Pons, 2005). Picture 2 was chosen for its high score on the latter personality trait (and moderate scores with respect to attractiveness and the other personality dimensions). Picture 3 got relatively moderate scores for all characteristics. Picture 4 was a picture yielding bad scores, both with respect to attractiveness and with respect to personality traits. ${ }^{8}$

\footnotetext{
${ }^{7}$ Baert and Decuypere (2014) showed that these characteristics affected the experimental hiring decisions of the testers in their role of recruiter.

${ }^{8}$ More concretely, Picture 1, Picture 2, Picture 3 and Picture 4 scored, on average, 4.34 (third highest out of 22 pictures), 3.53 (11/22), 4.22 (5/22) and 2.75 (22/22) on attractiveness; 4.66 (2/22), 4.32 (6/22), 4.11 (16/22) and 3.98 (18/22) on agreeableness; 4.43 (7/22), $4.86(1 / 22), 4.23(12 / 22)$ and 3.90 (15/22) on conscientiousness;
} 
The random assignment of one out of four pictures to each of the two job application template types was realised by a randomisation procedure in which we alternated between the 12 possible pairs of applications sent to employers. In addition, we alternated pairs who revealed their facial pictures by pasting it directly into their resume ${ }^{9}$ and pairs who made their pictures publicly available as their Facebook profile picture. For the latter pairs, no picture was added to their resume. For these pairs, the first name and surname of the candidates led, by searching it on Google or by submitting it to the Facebook search bar, to a single Facebook profile (and no other Google hits). These fictitious profiles were under our control and only publicly displayed the (current) profile picture of the candidate. For the former pairs, the common first name and surname combinations of the candidates' led to tens of Facebook profile pictures so that the employer could not screen the candidate through Facebook. It is important to mention that we made sure that the names we chose did not represent a different social background following Bloothooft and Onland (2011) who linked the suffix of the first name Dutch speaking parents choose for their children to these children's later wages. ${ }^{10}$

We hypothesise that candidates who reveal Picture 1 or Picture 2 as their resume picture have, given the beneficial scores of these pictures on perceived attractiveness and personality, better hiring chances than candidates revealing Picture 3, who have, in turn, better hiring chances than those revealing Picture 4. We have no a priori expectations concerning the relative treatment of candidates revealing Picture 1 versus candidates revealing Picture 2 as resume picture. In addition, supported by the evidence of employers reporting that they use

$5.13(1 / 22), 4.30(11 / 22), 4.49(7 / 22)$ and 3.66 (22/22) on emotional stability; 5.07 (3/22), 5.04 (4/22), 4.10 (13/22) and 2.88 (22/22) on extraversion; and 5.09 (2/22), 4.60 (10/22), $4.29(13 / 22)$ and 3.55 (22/22) on openness. The consensus in the peer-reviewed literature is that all these factors have a non-negative effect on productivity, except for agreeableness, for which, besides zero effects, both (slightly) positive and (slightly) negative effects have been found (Baert and Decuypere, 2014; Barrick and Mount, 1991; Heineck, 2011; Mueller and Plug, 2006)

${ }^{9}$ Several Flemish human resource managers confirmed that in Flanders, it is not uncommon to add a facial picture to one's resume.

10 These names were "Peter Baert", "Thomas De Groote", "Sven De Clerck" and "Bart De Sutter" when pasting Picture 1, Picture 2, Picture 3 and Picture 4, respectively, directly into the resume and "Thibaut Schoors", "Kjell Lievevrouw", "Joannes Bombeek" and "Bregt Van Acoleyen" when using the same pictures as Facebook profile pictures. 
Facebook in screening job candidates, as reviewed in Table 1, we expect the same ordering in terms of hiring chances, i.e., the highest for Picture 1 and Picture 2 and the lowest for Picture 4, when the pictures are used as Facebook profile pictures.

Concerning the relative effect of variation in Facebook profile pictures compared to the effect of these pictures when employed as resume pictures, we have no a priori expectations. On the one hand, the probability that a candidate's facial picture is seen is higher when it is pasted into his resume than when it is made available as a Facebook profile picture. Therefore, the chance of affecting hiring outcomes is higher for resume pictures than for Facebook profile pictures, ceteris paribus. On the other hand, the magnitude of the impact of a facial picture might be higher when it is seen as a Facebook profile picture than when it is seen as a resume picture. This may be the case if, as argued in Section 1, employers perceive Facebook profile pictures as more honest signals of applicants' ability and commitment than resume pictures (because job candidates might be not aware that employers screen their personal Facebook profile).

\subsection{Classification of Call-Back}

The combinations of application template types and experimental identities by facial picture were sent to the employers between 24 November 2013 and 20 April 2014, in an alternating order, each time with approximately 24 hours in between the pair members.

Call-backs were received by telephone voicemail or email. In our analysis, we follow the literature in distinguishing between two definitions of positive call-back. Positive call-back sensu stricto means the applicant was invited for an interview concerning the posted job. Positive call-back sensu lato also includes the request to contact the recruiter by telephone or to provide more information by email or the proposal of an alternative job. All call-backs received later than 30 days after sending out the application were neglected. 


\section{The Results}

\subsection{Positive Call-Back Ratios}

Table 2 presents the positive call-back rates for our fictitious job applicants by the picture we assigned to them (Picture 1, 2, 3 or 4 ) and by the way they revealed this picture (as a publicly available Facebook picture or as a resume picture). In Panel A, we follow the strict sense definition of positive call-back and in Panel B, the broad sense definition. In total, the candidates revealing Picture 1, Picture 2, Picture 3 and Picture 4 as a Facebook profile picture obtained a positive call-back in the strict sense (broad sense) in 9.8\% (22.7\%), 7.6\% (19.3\%), 7.6\% (22.7\%) and 5.3\% (17.0\%) of their applications, respectively. Except for one comparison (the positive call-back rate in broad sense is higher for those revealing Picture 3 as a Facebook profile picture than for those revealing Picture 2), these numbers perfectly follow our hypothesised ordering. On the other hand, the corresponding positive call-back rates are $6.8 \%(18.9 \%), 9.5 \%(20.4 \%), 5.7 \%(18.6 \%)$ and $5.3 \%(14.8 \%)$ for the candidates who pasted Picture 1, Picture 2, Picture 3 and Picture 4 directly into their resume. These numbers follow our hypothesised ordering without any exception.

\section{<Table 2 about here.>}

To compare the positive call-back rates outlined in Table 2 in a structured manner, we calculate a statistic frequently employed in correspondence studies, i.e., the positive call-back ratio (PCR). This statistic is calculated by dividing the positive call-back rate when using a particular picture (as Facebook profile or as resume picture) by the corresponding positive call-back rate when employing another particular picture. Table 3 (Table A.1 in Appendix A) presents the PCRs following the sensu stricto definition (sensu lato definition) of positive call-back, at the level of the total dataset and for various subsamples. As we use the positive call-back rates of the pictures with a lower index (picture number) as the numerator of these ratios and the corresponding call-back rates of the pictures 
with a higher index as the denominator, PCRs above 1 are expected given our hypotheses mentioned in Section 2.3. A single exception in this respect is the PCR comparing candidates with Picture 1 to candidates with Picture 2 (as we have no a priori expectations concerning their relative hiring chances).

\section{$<$ Table 3 about here.>}

At the level of the total dataset, Panel A.1 shows a PCR sensu stricto that is significantly higher than 1 when comparing candidates using Picture 1 as Facebook profile picture to candidates using Picture 4 for the same purpose. More concretely, the PCR is 1.857 , indicating that the former candidates obtained $85.7 \%$ more job interview invitations. In addition, the PCR sensu lato indicates a (statistically significant) 33.3\% higher probability of obtaining any positive reaction for both candidates using Picture 1 and Picture 3 compared to those using Picture 4. These findings are in line with our research hypotheses and indicate that Facebook profile picture appearance does affect hiring decisions.

The significant PCRs for the pairs of candidates pasting the facial pictures directly into their resumes (presented in Panel B.1) are also consistent with our expectations. When the pictures are employed as resume pictures, we find a statistically significant preference in respect of employers for Picture 2 above (Picture 3 and) Picture 4. Taken together, our findings based on the comparison of Panel A.1 and Panel B.1 might, given the relative strengths of Picture 1 and Picture 2 , be interpreted as suggestive evidence for Facebook pictures being screened more on attractiveness and resume pictures being screened more on personality traits. Or, alternatively, they might be explained by recruiters employing Facebook to screen candidates being relatively more interested in attractiveness and recruiters who do not employ Facebook being more interested in personality traits. However, our regression analysis below will show that, at least with respect to the probability of obtaining any positive reaction, we cannot reject that the variation in facial pictures does affect hiring chances equally when these pictures are used as Facebook profile pictures and when they are used as resume pictures. 
Next, we breakdown our ratios of unequal treatment by Facebook profile picture by proxies of (i) the education level of the candidates, (ii) the gender of the recruiter, (iii) the level of customer contact in the posted job and (iv) the bottleneck status of the occupation. First, by construction of the experiment, we observe two education levels, i.e., secondary education ("middle-educated") and tertiary education ("high-educated"). On the one hand, one could expect that higheducated candidates are screened more on Facebook as they seem to be more engaged on social media (Correa et al., 2010). On the other hand, theoretical and empirical studies show that, in general, unequal treatment based on subjective factors is lower for the high-educated as higher education degrees reduce uncertainty about job candidates (Baert et al., 2015a; Carlsson and Rooth, 2007; Taubman and Wales, 1974; Wood et al., 2009) and therefore, the need of making inferences about these candidates' ability based on informally gathered information about them. Second, the gender of the recruiter is proxied by the name of the contact person mentioned in the vacancy. Based on the fact that women employ social media in general and Facebook in particular more than men (Fitzgerald, 2012; Joinson, 2008), a higher surplus of beneficial Facebook profile pictures might be expected when recruiters are female, ceteris paribus. Third, the level of customer contact in the posted job is evaluated as intensive in case being customer-oriented is mentioned explicitly as a required skill in the vacancy. We expect the returns on perceived attractiveness and beneficial personality traits to be higher in jobs where customer contact is more important. Finally, concerning the labour market tightness in the occupation, following Baert et al. (2015a), we first matched each vacancy one-to-one with an occupation in the classification list of the Public Employment Agency of Flanders. For each of these occupations, we were able to look up their "bottleneck" status. This status is obtained by combining three statistical criteria concerning the labour market tightness in the occupation: (i) there must be at least 10 vacancies registered in the database of the Public Employment Agency for this occupation, (ii) the vacancy filling rate in this occupation must be lower than the median filling rate for all occupations together and (iii) the median duration until a vacancy in this occupation is filled must be 
greater than the median for all occupations together. When they must fill a bottleneck occupation, recruiters are expected to have a lower number of job candidates so that discriminating on (Facebook profile or resume) picture appearance is more costly. We therefore expect that the surplus of a high rated Facebook profile picture is higher in non-bottleneck occupations.

The statistics presented in Panels A.2, A.3, A.4 and A.5 of Table 3 (and Table A.1) show that our finding of more favourable hiring chances for candidates using Picture 1 (and Picture 3) as their Facebook profile picture compared to Picture 4 are driven by the applications (i) with high-educated candidates, (ii) with female recruiters, (iii) for posted jobs with high levels of customer contact and (iv) for nonbottleneck occupations. With respect to (i), our findings are in line with those of Madera and Chang (2011). In addition, the presented statistics are in line with our aforementioned expectations except for the breakdown of the PCRs by the level of customer contact in the posted job. We come back to the significance of these dimensions of heterogeneity in unequal treatment based on Facebook profile picture appearance later.

\subsection{Regression Analysis}

As we randomly assigned the four facial pictures to the two applications we sent to the tested vacancies, regressing positive call-back at the individual application level on these pictures and other candidate and vacancy characteristics should lead to exactly the same statistical results for a sample size approaching infinity (both for the subsample of candidates who used these pictures as Facebook profile picture and for the subsample of candidates who used them as resume picture). However, our sample size is finite. Therefore, observable and unobservable determinants of hiring outcomes that vary across vacancies may occur to correlate with the facial pictures used. To control for this potential correlation, we perform a regression analysis controlling for random effects at the vacancy level. ${ }^{11}$ In addition, this

\footnotetext{
${ }^{11}$ See, e.g., Verbeek (2004) for an introduction to random effects models. Basically, this approach allows one
} 
regression analysis allows us to measure the independent effect of the aforementioned variables (i), (ii), (iii) and (iv) interacted with the Facebook profile (or resume) picture of the candidate.

Table 4 and Table A.2 present our regression results for the subsamples of candidates revealing their facial picture as Facebook profile picture and resume picture, respectively. We regress the outcome of positive call-back sensu stricto (Models (1), (2) and (3)) and positive call-back sensu lato (Models (4), (5) and (6)) on various sets of variables by means of a linear probability model with random effects at the vacancy level. For reasons of comparability of the results for our different regression models, except for the picture indicators, all variables are normalised by subtracting their mean value among the candidates with Picture 1 , Picture 2 or Picture 3 as Facebook profile or resume picture. In what follows, we first focus on the results outlined in Table 4. Afterwards, we compare these results with the ones in Table A.2.

\section{<Table 4 about here.>}

In Model (1) and Model (4), we include only indicators of using Picture 1, Picture 2 and Picture 3 as the Facebook profile picture (thereby implicitly choosing Picture 4 as the reference picture) as explanatory variables. The regression results in Table 4 show that revealing Picture 1 as a Facebook profile picture increases the probability of job interview invitation with 2.6 percentage points (or $38.2 \%)^{12}$ and the probability of obtaining any positive reaction with 3.8 percentage points (or 20.9\%) in comparison with revealing Picture 4. In addition, revealing Picture 3 increases the probability of positive call-back sensu lato with 4.1 percentage points (or 22.5\%). These effects controlling for random effects at the vacancy level are somewhat lower than the ones derived from the corresponding PCRs mentioned above. Interestingly, after controlling for random effects at the vacancy level, we

to control for random factors, independently and identically distributed over, in our case, vacancies. As a result, the error term of the regression model consists of two components: a vacancy specific component and a remainder component. Random effects models can be estimated by means of the command "xtreg" in Stata. As an alternative, we estimated fixed effects models, i.e., linear regressions in which the intercept terms vary over the vacancies (Verbeek, 2004). This, however, yielded the same conclusions.

$1238.2 \%=0.026 / 0.068$. 
also find a weakly significant preference for candidates using Picture 1 as the Facebook profile picture compared to their counterparts using Picture 2.

Next, in Model (2) and Model (4), we include indicators of the template type employed and the submission order. As the picture assignment is, by construction, not correlated with them, the inclusion of these additional variables does not change the Facebook picture effects. Moreover, positive call-back outcomes vary neither by template type (as announced in Section 2.2) nor by place in the sending order.

Finally, in Model (3) and Model (6), we add interactions between the facial pictures used as the Facebook profile picture and indicator variables by which we want to investigate the heterogeneous effects of these pictures: (i) an indicator for high-educated candidates, (ii) an indicator for male recruiters, (iii) an indicator for jobs with intensive customer contact and (iv) an indicator for bottleneck occupations. On the one hand, the results for these models confirm our findings based on the descriptive analysis with respect to the higher surplus of high scored Facebook profile pictures for high-educated candidates and - to a lesser extent when recruiters are female. On the other hand, we do not find significant interactions with the indicator for jobs with intensive customer contact or the indicator for bottleneck occupations after controlling for random effects at the vacancy level.

Table A.2 presents the corresponding regression results when employing the subsample of candidates pasting the facial pictures directly into their resume. In line with Panel B.1 of Table 3 and Table A.1, we find the highest positive call-back rates when using Picture 2 as the resume picture. In addition, we find weakly significant evidence that the higher job interview invitation probability for candidates with this picture is driven by the observations for non-bottleneck occupations.

A remaining question is whether the variation in the facial pictures we use has a lower (or higher) effect on hiring chances when the photographs are used as the Facebook profile picture than when they are used as the resume picture. By 
comparing the effects of using Picture 1, Picture 2 and Picture 3 (in comparison with Picture 4) as the Facebook profile picture in Table 4 to the corresponding effects of pasting these pictures directly into one's resume in Table A.2, we observe (i) quite comparable effects with respect to Picture 1 and Picture 3 and (ii) a substantially higher effect of Picture 2 when used as the resume picture.

As a last exercise, which is reported in Table 5, we investigate the latter issue formally. We do this by pooling the data and regressing positive call-back on the picture indicators (used as the Facebook profile or resume picture) and interactions between the pictures assigned and an indicator of whether they were used as the Facebook profile picture. ${ }^{13}$ The latter interactions are key in this exercise. Model (1) and Model (2) follow the sensu stricto definition of positive callback, and Model (3) and Model (4) follow the sensu lato definition. In Model (1) and Model (2), we include flexible interactions between the three pictures and the indicator of their use as a Facebook profile picture. We find that Picture 2 is significantly more valued (in comparison with Picture 4) when used as a resume picture than when used as the Facebook profile picture. However, we do not find a difference in surplus for Picture 1 and Picture 3 (in comparison with Picture 4) by their use as a Facebook profile picture or resume picture. In addition, we can, at least with respect to the probability of positive call-back in broad sense, not reject that the additional surplus of using Picture 1, Picture 2 and Picture 3 as a Facebook profile picture (compared to using them as a resume picture) instead of Picture 4 is equal for these three pictures $(p=0.181)$. Therefore, in Model (2) and Model (4), we adopt a more restrictive specification in which only one general interaction between the assignment of Picture 1, Picture 2 or Picture 3 and the use of this picture as a Facebook profile picture is included. For this more restrictive specification, we cannot reject that the effect of these "better" pictures is indifferent by whether they are used as a Facebook profile or resume picture. Thus, except for one situation (the probability of positive call-back sensu stricto for individuals using Picture 2 compared to individuals using Picture 4), we cannot

\footnotetext{
${ }^{13}$ In addition, to control for a difference in call-back for the reference picture, i.e., Picture 4, in the situation in which it is used as a Facebook profile picture and the situation in which it is used as a resume picture, a dummy indicating members of pairs using their pictures as Facebook profile pictures is included.
} 
reject that the surplus for the "better" pictures is equal when they are used as a Facebook picture and when they are used as a resume picture.

\section{$<$ Table 5 about here.>}

\section{Conclusion}

In this study, we contributed to the literature measuring the use of social media in screening job candidates. We presented a systematic review of this literature and concluded that all former contributions to it were based on data self-reported by employers. We argued that this approach suffers from three methodological problems: (i) reported attitudes may deviate from actual hiring behaviour, (ii) employing social media does not mean letting social media affect hiring decisions and (iii) candidates differ in the available information on their online profile pages.

To overcome these issues, we conducted a field experiment in the Belgian labour market. Pairs of fictitious job applicants were sent to genuine job openings. To each application within a pair, we randomly assigned one out of four facial pictures varying in attractiveness and personality. For half of the vacancies, these pictures were directly pasted into the resumes, while for the other half, we assigned a candidate name to the resumes, which, by searching it on Google or by submitting it to the Facebook search bar, led to a single Facebook profile. These fictitious profiles were under our control and only publicly displayed the profile picture. By monitoring the subsequent reactions from the employer side, the effect of the Facebook profile pictures was identified directly and could be interpreted in a causal way. Due to the design of the experiment, we could measure the effect of the Facebook profile pictures as such and in comparison with their effect when pasted directly into the candidates' resumes.

We found that candidates with the most beneficial Facebook picture got approximately $39 \%$ more job interview invitations and $21 \%$ more positive reactions 
in a broad sense compared to candidates with the least beneficial picture. This surplus of a favourable Facebook picture was higher for the higher educated. In addition, we found suggestive evidence for a higher surplus when recruiters were female. Moreover, we could not reject that variation in Facebook profile pictures affects positive call-back in a broad sense with the same magnitude as (the same) variation in resume pictures. A potential explanation for this finding is the fact that only part of the recruiters screen Facebook is compensated for by their perception of Facebook profile pictures as more honest signals of applicants' ability and commitment.

An important limitation of the current study is that we measured only the impact of a very specific social media item, i.e., individuals' Facebook profile picture, on hiring chances. ${ }^{14}$ However, for many job candidates, this profile picture is the only element that they make publicly available on Facebook, and by extension - given that Facebook is by far the most popular social networking website - on social media. Thereby, this profile picture is often the only social media item employers are able to screen in practice. Nevertheless, we are in favour of future studies exploring whether other components of publicly available information also affect the employment opportunities of users of social networking sites. The relative importance of these components could, for instance, be studied by means of eye tracking experiments ${ }^{15}$ in which recruiters are asked to make fictitious hiring decisions based on job candidates' (fully public) social networking profiles and their eye movements when screening these profiles are followed (and analysed).

\footnotetext{
14 In addition, the reader might mention that correspondence experiments focus on a very particular outcome, i.e., call-back rates for first interviews. As a result, our findings do not allow making any statements about unequal treatment based on Facebook profile picture appearance in the later stages of the screening process. However, Bertrand and Mullainathan (2004) argue that a lower number of interview invitations is expected to be reflected in reduced job offers. Furthermore, because job interviews are costly, employers invite job candidates to an interview only if these applicants have a reasonable chance of getting the job.

${ }^{15}$ An example of an eye tracking experiment applied to unequal treatment in the labour market is Lahey et al. (2015).
} 


\section{References}

Back, M., Stopfer, J., Vazire, S., Gaddis, S., Schmukle, S., Egloff, B., Gosling, S. (2010): Facebook Profiles Reflect Actual Personality, Not Self-Idealization. Psychological Science, 20, 1-3.

Baert, S. (2014): Career Lesbians. Getting Hired for Not Having Kids? Industrial Relations, 45, 543-561.

Baert, S., Cockx, B., Gheyle, N., Vandamme, C. (2015a): Is There Less Discrimination in Occupations Where Recruitment Is Difficult? ILR Review, 68, 467500 .

Baert, S., Decuypere, L. (2014): Better sexy than flexy? A lab experiment assessing the impact of perceived attractiveness and personality traits on hiring decisions. Applied Economics Letters, 21, 597-601.

Baert, S., Norga, J., Thuy, Y., Van Hecke, M. (2015b): Getting Grey Hairs in the Labour Market. An Alternative Experiment on Age Discrimination. IZA Discussion Paper Series, 9289.

Barrick, M. R., Mount, M. K. (1991): The big five personality dimensions and job performance: a meta-analysis. Personnel Psychology, 44, 1-26.

Berkelaar, B. L., Scacco, J. M., Birdsell, J. L. (2015): The worker as politician: How online information and electoral heuristics shape personnel selection and careers. New Media \& Society, 17, 1377-1396.

Bertrand, M., Mullainathan, S. (2004): Are Emily and Greg more employable than Lakisha and Jamal? A field experiment on labor market discrimination. American Economic Review, 94, 991-1013.

Bloothooft, G., Onland, D. (2011): Socioeconomic determinants of first names. Names, 59, 25-41. 
Bohnert, D., Ross, W. H. (2010): The Influence of Social Networking Web Sites on the Evaluation of Job Candidates. Cyberpsychology, Behavior and Social Networking, 13, 341-347.

Boyd, D. M., Ellison, N. B. (2007): Social network sites: Definition, history and scholarship. Journal of Computer Mediated Education, 13, 210-230.

Brandenburg, C. (2008): Newest Way to Screen Job Applicants: A Social Networker's Nightmare. Federal Communications Law Journal, 60, 597-626.

Broughton, A., Foley, B., Ledermaier, S., Cox, A. (2013): The use of social media in the recruitment process. ACAS Research Papers, 03/13.

Brown, V. R., Vaughn, E. (2011): The Writing on the (Facebook) Wall: The Use of Social Networking Sites in Hiring Decisions. Journal of Business and Psychology, 26, 219-225.

Caers, R., Castelyns, V. (2011): Linkedln and Facebook in Belgium: The Influences and Biases of Social Network Sites in Recruitment and Selection Procedures. Social Science Computers Review, 29, 437-448.

Caers, R., De Freyter, T., De Couck, M., Stough, T., Vigna, C., Du Bois, C. (2013): Facebook: A literature review. New Media \& Society, 15, 984-1002.

CareerBuilder (2012): Thirty-seven percent of companies use social networks to research potential job candidates, according to new CareerBuilder Survey. Retrieved 28 August 2015 from http://www.careerbuilder.com/share/aboutus/pressreleasesdetail.aspx?id=pr691\&sd=4\%2F18\%2F2012\&e $d=4 \% 2 F 18 \% 2 F 2099$.

Carlsson, M., Rooth, D.-A. (2007): Evidence of ethnic discrimination in the Swedish labor market using experimental data. Labour Economics, 14, 716-729.

Chauhan, R. S., Buckley, M. R., Harvey, M. G. (2013): Facebook and personnel selection: What's the big deal? Organizational Dynamics, 42, 126-134. 
Clark, A. S. (2006): Employers look at Facebook, too. Retrieved 28 August 2015 from http://www.cbsnews.com/stories/2006/06/20/eveningnews/main1734920.shtml.

Correa, T., Hinsley, A. W., Gil de Zúñiga, H. (2010): Who interacts on the Web? The intersection of users' personality and social media use. Computers in Human Behavior, 26, 247-253.

Davison, H. K., Maraist, C. C., Bing, M. (2011): Friend or Foe? The Promise and Pitfalls of Using Social Networking Sites for HR Decisions. Journal of Business and Psychology, 26, 153-159.

Drydakis, N. (2009): Sexual orientation discrimination in the labour market. Labour Economics, 16, 364-372.

Drydakis, N. (2011): Women's Sexual Orientation and Labor Market Outcomes in Greece. Feminist Economics, 17, 89-117.

Du, W. (2007): Job candidates get tripped up by Facebook: Many students learn the hard way that online image can limit opportunity. Retrieved 28 August 2015 from http://www.msnbc.msn.com/id/20202935/print/1/displaymode/1098.

Elzweig, B., Peeples, D. K. (2009): Using social networking web sites in hiring and retention decisions. S.A.M. Advanced Management Journal, 74, 27-35.

Eriksson, S., Rooth, D.-O. (2014): Do Employers Use Unemployment as a Sorting Criterion When Hiring? Evidence from a Field Experiment. American Economic Review, 104, 1014-1039.

Facebook (2015): Our Mission. Retrieved 28 August 2015 from http://newsroom.fb.com/company-info.

Fitzgerald, B. (2012): More Women On Facebook, Twitter And Pinterest Than Men. Retrieved 28 August 2015 from http://www.huffingtonpost.com/2012/07/09/women-facebook-twitter-pinterest-n-1655164.html.

Gibbs, C., MacDonald, F., MacKay, K. (2015): Social media usage in hotel human 
resources: recruitment, hiring and communication. International Journal of Contemporary Hospitality Management, 27, 170-184.

Gosling, S. D., Gaddis, S., Vazire, S. (2008): First impressions from the environments that we create and inhabit. In Skowronski, J., Ambady, N. (Eds.): First impressions. New York: Guilford.

Gosling, S. D., Rentfrow, P. J., Swann, W. B. (2003): A very brief measure of the big-five personality domains. Journal of Research in Personality, 37, 504-28.

Heineck, G. (2011): Does it Pay to Be Nice? Personality and Earnings in the United Kingdom. ILR Review, 64, 1020-1038.

Heineck, G., Anger, S. (2010): The returns to cognitive abilities and personality traits in Germany. Labour Economics, 17, 535-546.

Joinson, A. N. (2008): 'Looking at', 'Looking up' or 'Keeping up with' people? Motives and uses of Facebook. CHI Proceedings, 2008, 1027-1036.

Kluemper, D. H., Rosen, P. A. (2009): Future employment selection methods: evaluating social networking web sites. Journal of Managerial Psychology, 24, 567580.

Kramer, N. C., Winter, S. (2008): Impression Management 2.0: The relationship of self-esteem, extraversion, self-efficacy and self-presentation within social networking sites. Journal of Media Psychology: Theories, Methods and Applications, 20, 106-113.

Kravets, D. (2013): Six states bar employers from demanding Facebook passwords. Retrieved 28 August 2015 from http://www.wired.com/threatlevel/2013/01/password-protected-states.

Kroft, K., Lange, F., Notowidigdo, M. J. (2013): Duration Dependence and Labor Market Conditions: Evidence from a Field Experiment. Quarterly Journal of Economics, 128, 1123-1167.

Lahey, J., Oxley, D. R., Alexander, G. (2015): Age Discrimination Using Resumes. 
Report Prepared for the Alfred P. Sloan Foundation. Retrieved 28 August 2015 from http://www.cla.auburn.edu/economics/assets/File/LaheyAgeDiscrimination.pdf.

Levinson, M. (2010): Social networking ever more critical to job search success. Retrieved 28 August 2015 from http://www.cio.com/article/2417135/careersstaffing/social-networking-ever-more-critical-to-job-search-success.html.

Lopez Bóo, F., Rossi, M., Urzúa, S. (2013): The labor market return to an attractive face: Evidence from a field experiment. Economics Letters, 118, 170-172.

Madera, J. M., Chang, W. (2011): Using Social Network Sites to Investigate Employees in the Hospitality Industry. International CHRIE Conference-Refereed Track, 20.

Mauzer-Fazio, M., Lei, L. (2015): "As rare as a panda." How facial attractiveness, gender, and occupation affect interview callbacks at Chinese firms. International Journal of Manpower, 36, 68-85.

Mueller, G., Plug, E. (2006): Estimating the effect of personality on male and female earnings. ILR Review, 60, 3-22.

Nikolaou, I. (2014): Social Networking Web Sites in Job Search and Employee Recruitment. International Journal of Selection and Assessment, 22, 179-189.

Nyhus, E., Pons, E. (2005): The effects of personality on earnings. Journal of Economic Psychology, 26, 363-384.

Pager, D. (2007): The use of field experiments for studies of employment discrimination: contributions, critiques, and directions for the future. Annals of the American Academy of Political and Social Science, 609, 104-133.

Pager, D., Quillian, L. (2005): Walking the talk? What Employers Say Versus What They Do. American Sociological Review, 70, 355-380.

Preston, J. (2011): Social media history becomes a new job hurdle. Retrieved 28 August 2015 from http://www.nytimes.com/2011/07/21/technology/social-mediahistory-becomes-a-new-job-hurdle.html. 
Rains, S. A., Brunner, S. R. (2015): What can we learn about social network sites by studying Facebook? A call and recommendations for research on social network sites. New Media \& Society, 17, 114-131.

Riach, P. A., Rich, J. (2002): Field Experiments of Discrimination in the Market Place. Economic Journal, 112, 480-518.

Rooth, D.-O. (2009): Obesity, Attractiveness, and Differential Treatment in Hiring: A Field Experiment. Journal of Human Resources, 44, 710-735.

Roth, P., Bobko, P., Van Iddekinge, C., Tatcher, J. (2013): Social Media in Employee-Selection-Related Decisions: A Research Agenda for Uncharted Territory. Journal of Management, 20, 1-30.

Roulin, N., Bangerter, A. (2013): Social Networking Websites in Personnel Selection. A Signaling Perspective on Recruiters' and Applicants' Perceptions. Journal of Personnel Psychology, 12, 143-151.

Ruffle, B., Shtudiner, Z. (2015): Are Good-Looking People More Employable? Management Science, 61, 1760-1776.

Shea, K., Wesley, J. (2006): How social networking sites affect students, career services and employers. NACE Journal, 66, 26-32.

SHRM (2011): SHRM survey findings: The use of social networking websites and online search engines in screening job candidates. Retrieved 28 August 2015 from http://www.shrm.org/research/surveyfindings/articles/pages/theuseofsocialnetwo rkingwebsitesandonlinesearchenginesinscreeningjobcandidates.aspx.

Slovensky, R., Ross, W. (2012): Should human resource managers use social media to screen job applicants? Managerial and legal issues in the USA. Info, 14, 55-69.

Smith, W. P., Kidder, D. (2010): You've been tagged! (Then again, maybe not): Employers and Facebook. Business Horizons, 53, 491-499. 
Stone, B. (2006): Web of risks: Students adore social-networking sites like Facebook, but indiscreet postings can mean really big trouble. Newsweek, 148, 76.

Taubman, P. J., Wales, T. (1974): Higher Education and Earnings: College as an Investment and Screening Device. Massachusetts: NBER Books.

Tufts, S. H., Jacobson, W. S., Stevens, M. S. (2015): Status Update: Social Media and Local Government Human Resource Practices. Review of Public Personnel Administration, 35, 193-207.

Verbeek, M. (2004): A Guide to Modern Econometrics. Chicester: John Wiley \& Sons Ltd.

Wilson, R. E., Gosling, S. D., Graham, L. T. (2012): A Review of Facebook Research in the Social Sciences. Perspectives on Psychological Science, 7, 203-220.

Wood, M., Hales, J., Purdon, S., Sejersen, T., Hayllar, O. (2009): A test for racial discrimination in recruitment practice in British cities. DWP Research Reports, 607.

Zeidner, R. (2007): How deep can you probe? HRMagazine, 52, 57-60.

Zhang, Y., Leung, L. (2015): A review of social networking service (SNS) research in communication journals from 2006 to 2011. New Media \& Society, 17, 10071024. 


\section{Appendix A: Additional Figures and Tables}

<Figure A.1 about here.>

<Figure A.2 about here.>

<Figure A.3 about here.>

<Figure A.4 about here.>

<Table A.1 about here.>

$<$ Table A.2 about here.> 
Figure A.1. Facial Picture 1.

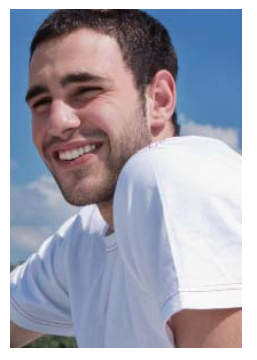

Figure A.2. Facial Picture 2.

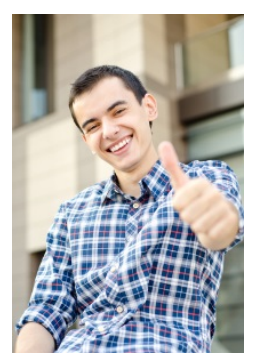

Figure A.3. Facial Picture 3.

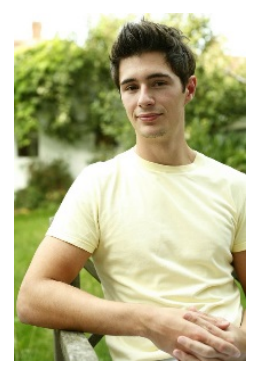

Figure A.4. Facial Picture 4.

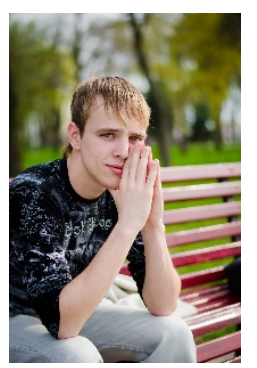


Table 1. Literature Review: Social Network Sites and Job Applicant Screening.

\begin{tabular}{|c|c|c|c|c|}
\hline (1) & (2) & (3) & (4) & (5) \\
\hline Study & $\begin{array}{l}\text { Country of data } \\
\text { gathering }\end{array}$ & $\begin{array}{l}\text { Year(s) of data } \\
\text { gathering }\end{array}$ & Method of data gathering & Main result(s) \\
\hline $\begin{array}{l}\text { Caers and } \\
\text { Castelyns (2011) }\end{array}$ & Belgium & 2010 & $\begin{array}{l}\text { Online questionnaire assessing } 731 \text { recruitment and selection } \\
\text { professionals. }\end{array}$ & $\begin{array}{l}23.4 \% \text { of the participants report that they look at personal Facebook profiles to } \\
\text { screen job candidates. } 34.2 \% \text { of the participants report that they look at personal } \\
\text { Linkedln profiles to screen job candidates. }{ }^{b}\end{array}$ \\
\hline $\begin{array}{l}\text { Gibbs et al. } \\
\text { (2015) }\end{array}$ & $\begin{array}{l}\text { Canada and } \\
\text { United States }\end{array}$ & $2013^{a}$ & $\begin{array}{l}\text { Online questionnaire assessing } 292 \text { human resource } \\
\text { managers at large hotels. }\end{array}$ & $\begin{array}{l}23.2 \% \text { of the participants report that they look at personal profile pages at SNWs } \\
\text { to screen job candidates. }\end{array}$ \\
\hline $\begin{array}{l}\text { Madera and } \\
\text { Chang (2011) }\end{array}$ & United States & $2010^{a}$ & $\begin{array}{l}\text { Paper and pencil questionnaire assessing } 50 \text { college } \\
\text { recruiters, recruitment and selection professionals, operation } \\
\text { managers and general managers. }\end{array}$ & $\begin{array}{l}50.0 \% \text { of the participants report that they look at personal profile pages at SNWs } \\
\text { to screen job candidates. }\end{array}$ \\
\hline Nikolaou (2014) & Greece & 2009 and 2010 & $\begin{array}{l}\text { Online questionnaire assessing } 122 \text { recruitment and selection } \\
\text { professionals. }\end{array}$ & $\begin{array}{l}8.1 \% \text { of the participants report that they look at personal Facebook profiles to } \\
\text { screen job candidates. } 21.1 \% \text { of the participants report that they look at personal } \\
\text { Linkedln profiles to screen job candidates. }{ }^{\text {a, }} \text { ( }\end{array}$ \\
\hline $\begin{array}{l}\text { Roulin and } \\
\text { Bangerter } \\
\text { (2013) }\end{array}$ & $\begin{array}{l}\text { France and } \\
\text { Switzerland }\end{array}$ & $2011^{a}$ & $\begin{array}{l}\text { Online questionnaire assessing } 96 \text { recruitment and selection } \\
\text { professionals. }\end{array}$ & $\begin{array}{l}19.8 \% \text { of the participants report that they look at personal Facebook profiles to } \\
\text { screen job candidates. } 40.6 \% \text { of the participants report that they look at personal } \\
\text { LinkedIn profiles to screen job candidates. }\end{array}$ \\
\hline $\begin{array}{l}\text { Tufts et al. } \\
\text { (2015) }\end{array}$ & United States & 2012 and 2013 & $\begin{array}{l}\text { Online questionnaire assessing } 48 \text { human resource managers } \\
\text { at local governments. }\end{array}$ & $\begin{array}{l}12.5 \% \text { of the participants report that they look at personal profile pages at SNWs } \\
\text { to screen job candidates. }\end{array}$ \\
\hline
\end{tabular}


Table 2. The Probability of Positive Call-Back by Facebook Profile and Resume Pictures: Call-Back Rates.

\begin{tabular}{|c|c|c|c|c|}
\hline & (1) & (2) & (3) & (4) \\
\hline & $\begin{array}{l}\text { Positive call-back } \\
\text { rate Picture } 1\end{array}$ & $\begin{array}{l}\text { Positive call-back } \\
\text { rate Picture } 2\end{array}$ & $\begin{array}{l}\text { Positive call-back } \\
\text { rate Picture } 3\end{array}$ & $\begin{array}{l}\text { Positive call-back } \\
\text { rate Picture } 4\end{array}$ \\
\hline \multicolumn{5}{|l|}{ A. Positive call-back sensu stricto } \\
\hline A.1. Pictures used as Facebook profile pictures & 0.098 & 0.076 & 0.076 & 0.053 \\
\hline A.2. Pictures used as resume pictures & 0.068 & 0.095 & 0.057 & 0.053 \\
\hline \multicolumn{5}{|l|}{ B. Positive call-back sensu lato } \\
\hline B.1. Pictures used as Facebook profile pictures & 0.227 & 0.193 & 0.227 & 0.170 \\
\hline B.2. Pictures used as resume pictures & 0.189 & 0.204 & 0.186 & 0.148 \\
\hline
\end{tabular}


Table 3. The Probability of Positive Call-Back Sensu Stricto by Facebook Profile and Resume Pictures: Positive Call-Back Ratios.

\begin{tabular}{|c|c|c|c|c|c|c|}
\hline & (1) & (2) & (3) & (4) & (5) & (6) \\
\hline & $\begin{array}{l}\text { PCR Picture } \\
1 \text { versus } \\
\text { Picture } 2\end{array}$ & $\begin{array}{l}\text { PCR Picture } \\
1 \text { versus } \\
\text { Picture } 3\end{array}$ & $\begin{array}{l}\text { PCR Picture } \\
1 \text { versus } \\
\text { Picture } 4\end{array}$ & $\begin{array}{l}\text { PCR Picture } \\
2 \text { versus } \\
\text { Picture } 3\end{array}$ & $\begin{array}{l}\text { PCR Picture } \\
2 \text { versus } \\
\text { Picture } 4\end{array}$ & $\begin{array}{l}\text { PCR Picture } \\
3 \text { versus } \\
\text { Picture } 4\end{array}$ \\
\hline \multicolumn{7}{|c|}{ A. Pictures used as Facebook profile picture } \\
\hline A.1. All vacancies $(N=528)$ & $\begin{array}{l}1.300 \\
{[1.099]}\end{array}$ & $\begin{array}{l}1.300 \\
{[1.047]}\end{array}$ & $\begin{array}{l}1.857^{* *} \\
{[2.343]}\end{array}$ & $\begin{array}{l}1.000 \\
{[0.000]}\end{array}$ & $\begin{array}{l}1.429 \\
{[1.138]}\end{array}$ & $\begin{array}{l}1.429 \\
{[1.218]}\end{array}$ \\
\hline \multicolumn{7}{|c|}{ A.2. Classified by education level of candidates } \\
\hline Middle-educated ( $N=264)$ & $\begin{array}{l}0.833 \\
{[0.339]}\end{array}$ & $\begin{array}{l}1.000 \\
{[0.000]}\end{array}$ & $\begin{array}{l}1.667 \\
{[0.825]}\end{array}$ & $\begin{array}{l}1.200 \\
{[0.444]}\end{array}$ & $\begin{array}{l}2.000 \\
{[1.015]}\end{array}$ & $\begin{array}{l}1.667 \\
{[0.828]}\end{array}$ \\
\hline High-educated ( $N=264)$ & $\begin{array}{l}1.500 \\
{[1.539]}\end{array}$ & $\begin{array}{l}1.400 \\
{[1.217]}\end{array}$ & $\begin{array}{l}1.909 * * \\
{[2.246]}\end{array}$ & $\begin{array}{l}0.933 \\
{[0.254]}\end{array}$ & $\begin{array}{l}1.273 \\
{[0.693]}\end{array}$ & $\begin{array}{l}1.364 \\
{[0.942]}\end{array}$ \\
\hline \multicolumn{7}{|l|}{ A.3. Classified by gender of recruiter } \\
\hline Female $(N=272)$ & $\begin{array}{l}1.545 \\
{[1.474]}\end{array}$ & $\begin{array}{l}2.079 * * \\
{[2.123]}\end{array}$ & $\begin{array}{l}1.767^{*} \\
{[1.759]}\end{array}$ & $\begin{array}{l}1.345 \\
{[0.869]}\end{array}$ & $\begin{array}{l}1.143 \\
{[0.345]}\end{array}$ & $\begin{array}{l}0.850 \\
{[0.370]}\end{array}$ \\
\hline Male $(N=192)$ & $\begin{array}{l}0.824 \\
{[0.364]}\end{array}$ & $\begin{array}{l}0.659 \\
{[0.825]}\end{array}$ & $\begin{array}{l}1.176 \\
{[0.739]}\end{array}$ & $\begin{array}{l}0.800 \\
{[0.581]}\end{array}$ & $\begin{array}{l}1.427 \\
{[0.601]}\end{array}$ & $\begin{array}{l}1.783 \\
{[1.400]}\end{array}$ \\
\hline \multicolumn{7}{|c|}{ A.4. Classified by level of customer contact in the posted job } \\
\hline No intensive contact $(N=283)$ & $\begin{array}{l}1.371 \\
{[1.232]}\end{array}$ & $\begin{array}{l}1.452 \\
{[1.328]}\end{array}$ & $\begin{array}{l}1.995^{* *} \\
{[2.184]}\end{array}$ & $\begin{array}{l}1.058 \\
{[0.181]}\end{array}$ & $\begin{array}{l}1.455 \\
{[0.958]}\end{array}$ & $\begin{array}{l}1.375 \\
{[0.901]}\end{array}$ \\
\hline Intensive contact $(\mathrm{N}=245)$ & $\begin{array}{l}1.076 \\
{[0.141]}\end{array}$ & $\begin{array}{l}1.008 \\
{[0.016]}\end{array}$ & $\begin{array}{l}1.495 \\
{[0.848]}\end{array}$ & $\begin{array}{l}0.937 \\
{[0.221]}\end{array}$ & $\begin{array}{l}1.389 \\
{[0.631]}\end{array}$ & $\begin{array}{l}1.482 \\
{[0.756]}\end{array}$ \\
\hline \multicolumn{7}{|c|}{ A.5. Classified by bottleneck status of occupation } \\
\hline No bottleneck $(N=385)$ & $\begin{array}{l}1.282 \\
{[0.909]}\end{array}$ & $\begin{array}{l}1.340 \\
{[1.065]}\end{array}$ & $\begin{array}{l}2.396^{* *} \\
{[2.546]}\end{array}$ & $\begin{array}{l}1.045 \\
{[0.169]}\end{array}$ & $\begin{array}{l}1.869^{*} \\
{[1.691]}\end{array}$ & $\begin{array}{l}1.788 \\
{[1.544]}\end{array}$ \\
\hline Bottleneck ( $N=143)$ & $\begin{array}{l}1.394 \\
{[0.684]}\end{array}$ & $\begin{array}{l}1.183 \\
{[0.773]}\end{array}$ & $\begin{array}{l}1.113 \\
{[0.266]}\end{array}$ & $\begin{array}{l}0.848 \\
{[0.336]}\end{array}$ & $\begin{array}{l}0.798 \\
{[0.366]}\end{array}$ & $\begin{array}{l}0.940 \\
{[0.131]}\end{array}$ \\
\hline \multicolumn{7}{|l|}{ B. Pictures used as resume picture } \\
\hline B.1. All vacancies $(\mathrm{N}=528)$ & $\begin{array}{l}0.720 \\
{[1.202]}\end{array}$ & $\begin{array}{l}1.200 \\
{[0.577]}\end{array}$ & $\begin{array}{l}1.286 \\
{[0.950]}\end{array}$ & $\begin{array}{l}1.667^{* *} \\
{[2.194]}\end{array}$ & $\begin{array}{l}1.785^{* *} \\
{[1.984]}\end{array}$ & $\begin{array}{l}1.071 \\
{[0.198]}\end{array}$ \\
\hline
\end{tabular}

The positive call-back ratio (PCR) is calculated by dividing the positive call-back rate when using a particular picture by the corresponding positive call-back rate when using another particular picture. T-statistics, indicating whether the ratios are significantly different from 1 and based on standard errors corrected for clustering at the vacancy level, are between brackets. ${ }^{*}\left({ }^{* *}\right)$ indicates significance at the $10 \%$ (5\%) significance level. The number of jobs with a female or a male recruiter does not equal the total number of vacancies, as for some vacancies, we could not identify the gender of the recruiter. 
Table 4. The Probability of Positive Call-Back by Facebook Profile Picture: Regression Analysis.

\begin{tabular}{|c|c|c|c|c|c|c|}
\hline & (1) & (2) & (3) & (4) & (5) & (6) \\
\hline Picture 1 & $0.026 *(0.014)$ & $0.026^{*}(0.014)$ & $0.027 *(0.014)$ & $0.038^{* *}(0.019)$ & $0.038^{* *}(0.019)$ & $0.039 * *(0.020)$ \\
\hline Picture 2 & $0.000(0.011)$ & $0.001(0.011)$ & $0.003(0.011)$ & $0.011(0.017)$ & $0.011(0.018)$ & $0.012(0.018)$ \\
\hline Picture 3 & $0.006(0.010)$ & $0.006(0.010)$ & $0.008(0.010)$ & $0.041 * *(0.021)$ & $0.041^{* *}(0.021)$ & $0.041 * *(0.021)$ \\
\hline Application template Type A (normalised) & & $0.004(0.007)$ & $0.004(0.007)$ & & $0.019(0.012)$ & $0.019(0.012)$ \\
\hline First application sent (normalised) & & $-0.008(0.007)$ & $-0.006(0.007)$ & & $0.000(0.012)$ & $0.003(0.012)$ \\
\hline Picture 1 x High-educated (normalised) & & & $0.053^{* *}(0.027)$ & & & $0.082 * *(0.036)$ \\
\hline Picture $2 \times$ High-educated (normalised) & & & $0.014(0.020)$ & & & $0.062 *(0.035)$ \\
\hline Picture 3 x High-educated (normalised) & & & $0.054^{* * *}(0.019)$ & & & $0.125 * * *(0.038)$ \\
\hline Picture 1 x Male recruiter (normalised) & & & $-0.042 *(0.023)$ & & & $-0.046(0.033)$ \\
\hline Picture $2 \times$ Male recruiter (normalised) & & & $0.016(0.020)$ & & & $0.009(0.033$ \\
\hline Picture $3 \times$ Male recruiter (normalised) & & & $-0.029(0.020)$ & & & $-0.016(0.037)$ \\
\hline Picture $1 \times$ Vacancy with intensive customer contact (normalised) & & & $-0.002(0.028)$ & & & $0.037(0.037)$ \\
\hline Picture $2 \times$ Vacancy with intensive customer contact (normalised) & & & $-0.030(0.020)$ & & & $-0.015(0.035)$ \\
\hline Picture $3 \times$ Vacancy with intensive customer contact (normalised) & & & $-0.010(0.018)$ & & & $0.010(0.038)$ \\
\hline Picture 1 x Bottleneck occupation (normalised) & & & $-0.028(0.023)$ & & & $-0.018(0.037)$ \\
\hline Picture $2 \times$ Bottleneck occupation (normalised) & & & $-0.026(0.021)$ & & & $-0.038(0.040)$ \\
\hline Picture $3 \times$ Bottleneck occupation (normalised) & & & $0.004(0.019)$ & & & $0.046(0.044)$ \\
\hline Constant & $0.068^{* * *}(0.012)$ & $0.068^{* * *}(0.012)$ & $0.067^{* * *}(0.014)$ & $0.182 * * *(0.019)$ & $0.180 * * *(0.019)$ & $0.171^{* * *}(0.020)$ \\
\hline Dependent variable: positive call-back sensu stricto & Yes & Yes & Yes & No & No & No \\
\hline Dependent variable: positive call-back sensu lato & No & No & No & Yes & Yes & Yes \\
\hline Random effects at the vacancy level & Yes & Yes & Yes & Yes & Yes & Yes \\
\hline F-test for equality of coefficients for "Picture 1" and "Picture 2" (p-value) & 0.068 & 0.068 & 0.075 & 0.205 & 0.206 & 0.201 \\
\hline F-test for equality of coefficients for "Picture 1" and "Picture 3" ( $p$-value) & 0.101 & 0.100 & 0.107 & 0.909 & 0.909 & 0.906 \\
\hline F-test for equality of coefficients for "Picture 2" and "Picture 3" ( $p$-value) & 0.656 & 0.657 & 0.681 & 0.160 & 0.160 & 0.158 \\
\hline Observations & 1,056 & 1,056 & 1,056 & 1,056 & 1,056 & 1,056 \\
\hline
\end{tabular}

The presented results are linear probability model estimates with standard errors in parentheses. Except for the picture indicators, all variables are normalised by subtracting their mean value among the candidates with Picture 1, Picture 2 or Picture 3 as their Facebook profile picture. ${ }^{*}(* *)((* *))$ indicates significance at the $10 \%(5 \%)((1 \%))$ significance level. 
Table 5. The Probability of Positive Call-Back by Facebook Profile and Resume Picture: Regression Analysis.

\begin{tabular}{|c|c|c|c|c|}
\hline & (1) & (2) & (3) & (4) \\
\hline Picture 1 & $0.027 * *(0.010)$ & $0.027 * *(0.010)$ & $0.039 * *(0.015)$ & $0.039 * *(0.015)$ \\
\hline Picture 2 & $0.026 * * *(0.010)$ & $0.026^{* * *}(0.010)$ & $0.035^{* *}(0.014)$ & $0.035^{* *}(0.014)$ \\
\hline Picture 3 & $0.013(0.009)$ & $0.013(0.009)$ & $0.040 * * *(0.015)$ & $0.040 * * *(0.015$ \\
\hline Picture $1 \times$ Used as Facebook profile picture (normalised) & $0.002(0.021)$ & & $0.001(0.030)$ & \\
\hline Picture $2 \times$ Used as Facebook profile picture (normalised) & $-0.047^{* *}(0.020)$ & & $-0.047 *(0.028)$ & \\
\hline Picture $3 \times$ Used as Facebook profile picture (normalised) & $-0.012(0.017)$ & & $0.002(0.030)$ & \\
\hline Picture 1, Picture 2 or Picture 3 used as Facebook profile picture (normalised) & & $-0.019(0.016)$ & & $-0.015(0.023)$ \\
\hline Pictures used as Facebook profile picture (normalised) & $0.022(0.017)$ & $0.022(0.017)$ & $0.034(0.027)$ & $0.034(0.027)$ \\
\hline Constant & $0.056 * * *(0.009)$ & $0.056^{* * *}(0.009)$ & $0.165^{* * *}(0.014)$ & $0.165^{* * *}(0.014$ \\
\hline Dependent variable: positive call-back sensu stricto & Yes & Yes & No & No \\
\hline Dependent variable: positive call-back sensu lato & No & No & Yes & Yes \\
\hline Random effects at the vacancy level & Yes & Yes & Yes & Yes \\
\hline F-test for equality of coefficients for "Picture 1" and "Picture 2" ( $p$-value) & 0.942 & 0.943 & 0.842 & 0.842 \\
\hline F-test for equality of coefficients for "Picture 1" and "Picture 3 " ( $p$-value) & 0.129 & 0.129 & 0.905 & 0.905 \\
\hline F-test for equality of coefficients for "Picture 2" and "Picture 3 " ( $p$-value) & 0.121 & 0.121 & 0.734 & 0.734 \\
\hline $\begin{array}{l}\text { F-test for equality of coefficients for "Picture } 1 \times \text { Used as Facebook profile picture", "Picture } 2 \times \text { Used as Facebook } \\
\text { profile picture" and "Picture } 3 \times \text { Used as Facebook profile picture" (p-value) }\end{array}$ & 0.040 & - & 0.181 & - \\
\hline Observations & 2112 & 2112 & 2112 & 2112 \\
\hline
\end{tabular}

The presented results are linear probability model estimates with standard errors in parentheses. Except for the picture indicators, all variables are normalised by subtracting their mean value among the candidates with Picture 1, Picture 2 or Picture 3 as their Facebook profile or resume picture. ${ }^{*}\left({ }^{* *}\right)\left(\left({ }^{* * *}\right)\right)$ indicates significance at the $10 \%(5 \%)((1 \%))$ significance level. 
Table A.1. The Probability of Positive Call-Back Sensu Lato by Facebook Profile and Resume Pictures: Positive Call-Back Ratios.

\begin{tabular}{|c|c|c|c|c|c|c|}
\hline & (1) & (2) & (3) & (4) & (5) & (6) \\
\hline & $\begin{array}{l}\text { PCR Picture } \\
1 \text { versus } \\
\text { Picture } 2\end{array}$ & $\begin{array}{l}\text { PCR Picture } \\
1 \text { versus } \\
\text { Picture } 3\end{array}$ & $\begin{array}{l}\text { PCR Picture } \\
1 \text { versus } \\
\text { Picture } 4\end{array}$ & $\begin{array}{l}\text { PCR Picture } \\
2 \text { versus } \\
\text { Picture } 3\end{array}$ & $\begin{array}{l}\text { PCR Picture } \\
2 \text { versus } \\
\text { Picture } 4\end{array}$ & $\begin{array}{l}\text { PCR Picture } \\
3 \text { versus } \\
\text { Picture } 4\end{array}$ \\
\hline \multicolumn{7}{|c|}{ A. Pictures used as Facebook profile picture } \\
\hline A.1. All vacancies $(N=528)$ & $\begin{array}{l}1.176 \\
{[1.092]}\end{array}$ & $\begin{array}{l}1.000 \\
{[0.000]}\end{array}$ & $\begin{array}{l}1.333^{* *} \\
{[1.974]}\end{array}$ & $\begin{array}{l}0.850 \\
{[1.149]}\end{array}$ & $\begin{array}{l}1.133 \\
{[0.768]}\end{array}$ & $\begin{array}{l}1.333^{*} \\
{[1.847]}\end{array}$ \\
\hline \multicolumn{7}{|c|}{ A.2. Classified by education level of candidates } \\
\hline Middle-educated ( $N=264)$ & $\begin{array}{l}1.000 \\
{[0.000]}\end{array}$ & $\begin{array}{l}1.250 \\
{[0.820]}\end{array}$ & $\begin{array}{l}1.333 \\
{[1.029]}\end{array}$ & $\begin{array}{l}1.250 \\
{[0.832]}\end{array}$ & $\begin{array}{l}1.333 \\
{[1.029]}\end{array}$ & $\begin{array}{l}1.067 \\
{[0.827]}\end{array}$ \\
\hline High-educated $(N=264)$ & $\begin{array}{l}1.290 \\
{[1.359]}\end{array}$ & $\begin{array}{l}0.909 \\
{[0.604]}\end{array}$ & $\begin{array}{l}1.333^{*} \\
{[1.712]}\end{array}$ & $\begin{array}{l}0.705^{* *} \\
{[2.134]}\end{array}$ & $\begin{array}{l}1.033 \\
{[0.167]}\end{array}$ & $\begin{array}{l}1.467^{* *} \\
{[2.157]}\end{array}$ \\
\hline \multicolumn{7}{|l|}{ A.3. Classified by gender of recruiter } \\
\hline Female ( $N=272)$ & $\begin{array}{l}1.360 \\
{[1.558]}\end{array}$ & $\begin{array}{l}1.188 \\
{[0.875]}\end{array}$ & $\begin{array}{l}1.325 \\
{[1.461]}\end{array}$ & $\begin{array}{l}0.874 \\
{[0.674]}\end{array}$ & $\begin{array}{l}0.974 \\
{[0.111]}\end{array}$ & $\begin{array}{l}1.115 \\
{[0.470]}\end{array}$ \\
\hline Male $(N=192)$ & $\begin{array}{l}0.873 \\
{[0.473]}\end{array}$ & $\begin{array}{l}0.688 \\
{[1.424]}\end{array}$ & $\begin{array}{l}1.037 \\
{[0.141]}\end{array}$ & $\begin{array}{l}0.788 \\
{[0.996]}\end{array}$ & $\begin{array}{l}1.189 \\
{[0.633]}\end{array}$ & $\begin{array}{l}1.508^{*} \\
{[1.755]}\end{array}$ \\
\hline \multicolumn{7}{|c|}{ A.4. Classified by level of customer contact in the posted job } \\
\hline No intensive contact $(\mathrm{N}=283)$ & $\begin{array}{l}1.191 \\
{[0.898]}\end{array}$ & $\begin{array}{l}1.024 \\
{[0.130]}\end{array}$ & $\begin{array}{l}1.560 * * \\
{[2.076]}\end{array}$ & $\begin{array}{l}0.860 \\
{[0.760]}\end{array}$ & $\begin{array}{l}1.309 \\
{[1.089]}\end{array}$ & $\begin{array}{l}1.523^{*} \\
{[1.918]}\end{array}$ \\
\hline Intensive contact ( $N=245)$ & $\begin{array}{l}1.162 \\
{[0.656]}\end{array}$ & $\begin{array}{l}0.972 \\
{[0.131]}\end{array}$ & $\begin{array}{l}1.153 \\
{[0.714]}\end{array}$ & $\begin{array}{l}0.837 \\
{[0.879]}\end{array}$ & $\begin{array}{l}0.992 \\
{[0.037]}\end{array}$ & $\begin{array}{l}1.186 \\
{[0.768]}\end{array}$ \\
\hline \multicolumn{7}{|c|}{ A.5. Classified by bottleneck status of occupation } \\
\hline No bottleneck ( $N=385$ ) & $\begin{array}{l}1.128 \\
{[0.709]}\end{array}$ & $\begin{array}{l}1.029 \\
{[0.177]}\end{array}$ & $\begin{array}{l}1.361^{*} \\
{[1.720]}\end{array}$ & $\begin{array}{l}0.911 \\
{[0.564]}\end{array}$ & $\begin{array}{l}1.206 \\
{[1.013]}\end{array}$ & $\begin{array}{l}1.323 \\
{[1.498]}\end{array}$ \\
\hline Bottleneck ( $N=143$ ) & $\begin{array}{l}1.352 \\
{[0.987]}\end{array}$ & $\begin{array}{l}0.928 \\
{[0.263]}\end{array}$ & $\begin{array}{l}1.272 \\
{[0.970]}\end{array}$ & $\begin{array}{l}0.686 \\
{[1.341]}\end{array}$ & $\begin{array}{l}0.940 \\
{[0.177]}\end{array}$ & $\begin{array}{l}1.370 \\
{[1.105]}\end{array}$ \\
\hline \multicolumn{7}{|l|}{ B. Pictures used as resume picture } \\
\hline B.1. All vacancies $(\mathrm{N}=528)$ & $\begin{array}{l}0.926 \\
{[0.490]}\end{array}$ & $\begin{array}{l}1.020 \\
{[0.123]}\end{array}$ & $\begin{array}{l}1.282 \\
{[1.500]}\end{array}$ & $\begin{array}{l}1.102 \\
{[0.666]}\end{array}$ & $\begin{array}{l}1.385^{*} \\
{[1.889]}\end{array}$ & $\begin{array}{l}1.256 \\
{[1.314]}\end{array}$ \\
\hline
\end{tabular}

The positive call-back ratio (PCR) is calculated by dividing the positive call-back rate when using a particular picture by the corresponding positive call-back rate when using another particular picture. T-statistics, indicating whether the ratios are significantly different from 1 and based on standard errors corrected for clustering at the vacancy level, are between brackets. * $\left({ }^{* *}\right)$ indicates significance at the $10 \%$ (5\%) significance level. The number of jobs with a female or a male recruiter does not equal the total number of vacancies, as for some vacancies, we could not identify the gender of the recruiter. 
Table A.2. The Probability of Positive Call-Back by Resume Picture: Regression Analysis.

\begin{tabular}{|c|c|c|c|c|c|c|}
\hline & (1) & (2) & (3) & (4) & (5) & (6) \\
\hline Picture 1 & $0.025(0.015)$ & $0.025(0.015)$ & $0.027(0.016)$ & $0.038 *(0.023)$ & $0.038 *(0.023)$ & $0.040 *(0.023)$ \\
\hline Picture 2 & $0.049 * * *(0.016)$ & $0.049 * * *(0.016)$ & $0.049 * * *(0.016)$ & $0.059 * * *(0.022)$ & $0.059 * * *(0.022)$ & $0.059 * * *(0.022)$ \\
\hline Picture 3 & $0.018(0.014)$ & $0.018(0.014)$ & $0.020(0.014)$ & $0.039 *(0.021)$ & $0.039 *(0.022)$ & $0.040 *(0.022)$ \\
\hline Application template Type A (normalised) & & $-0.010(0.010)$ & $-0.008(0.011)$ & & $-0.015(0.014)$ & $-0.007(0.015)$ \\
\hline First application sent (normalised) & & $-0.010(0.010)$ & $-0.008(0.011)$ & & $-0.008(0.014)$ & $-0.000(0.014)$ \\
\hline Picture 1 x High-educated (normalised) & & & $0.015(0.024)$ & & & $0.060(0.040)$ \\
\hline Picture 2 x High-educated (normalised) & & & $-0.004(0.034)$ & & & $0.032(0.039)$ \\
\hline Picture $3 \times$ High-educated (normalised) & & & $0.020(0.021)$ & & & $0.074 *(0.038)$ \\
\hline Picture $1 \times$ Male recruiter (normalised) & & & $-0.019(0.028)$ & & & $-0.045(0.044)$ \\
\hline Picture $2 \times$ Male recruiter (normalised) & & & $-0.015(0.032)$ & & & $-0.059(0.040)$ \\
\hline Picture $3 \times$ Male recruiter (normalised) & & & $-0.019(0.021)$ & & & $0.007(0.040)$ \\
\hline Picture 1 x Vacancy with intensive customer contact (normalised) & & & $0.018(0.026)$ & & & $-0.004(0.043)$ \\
\hline Picture 2 x Vacancy with intensive customer contact (normalised) & & & $0.028(0.033)$ & & & $0.006(0.038)$ \\
\hline Picture $3 \times$ Vacancy with intensive customer contact (normalised) & & & $0.019(0.021)$ & & & $-0.041(0.034)$ \\
\hline Picture 1 x Bottleneck occupation (normalised) & & & $-0.030(0.021)$ & & & $-0.019(0.053)$ \\
\hline Picture $2 \times$ Bottleneck occupation (normalised) & & & $-0.049 *(0.027)$ & & & $0.001(0.048)$ \\
\hline Picture $3 \times$ Bottleneck occupation (normalised) & & & $-0.032(0.026)$ & & & $0.005(0.047)$ \\
\hline Constant & $0.045^{* * *}(0.013)$ & $0.045^{* * *}(0.013)$ & $0.044 * * *(0.013)$ & $0.148^{* * *}(0.019)$ & $0.148 * * *(0.019)$ & $0.148^{* * *}(0.019)$ \\
\hline Dependent variable: positive call-back sensu stricto & Yes & Yes & Yes & No & No & No \\
\hline Dependent variable: positive call-back sensu lato & No & No & No & Yes & Yes & Yes \\
\hline Random effects at the vacancy level & Yes & Yes & Yes & Yes & Yes & Yes \\
\hline F-test for equality of coefficients for "Picture 1" and "Picture 2" ( $p$-value) & 0.126 & 0.126 & 0.148 & 0.378 & 0.381 & 0.421 \\
\hline F-test for equality of coefficients for "Picture 1 " and "Picture 3 " ( $p$-value) & 0.580 & 0.580 & 0.592 & 0.959 & 0.961 & 0.970 \\
\hline F-test for equality of coefficients for "Picture 2" and "Picture 3" (p-value) & 0.016 & 0.016 & 0.020 & 0.341 & 0.342 & 0.374 \\
\hline Observations & 1,056 & 1,056 & 1,056 & 1,056 & 1,056 & 1,056 \\
\hline
\end{tabular}

The presented results are linear probability model estimates with standard errors in parentheses. Except for the picture indicators, all variables are normalised by subtracting their mean value among the candidates with Picture 1, Picture 2 or Picture 3 as resume picture. ${ }^{*}\left({ }^{* *}\right)((* * *))$ indicates significance at the $10 \%(5 \%)((1 \%))$ significance level. 